\title{
Pengaruh Capital Adequacy Ratio (CAR), Loan to Deposit Ratio (LDR), Biaya Operasional dan Pendapatan Operasional (BOPO) terhadap Return on Asset (ROA) pada Perbankan yang Terdaftar di Bursa Efek Indonesia
}

\author{
Syamsiah1, Abdul Rahman Mus², Asdar Djamereng ${ }^{3}$ \\ 1 Program Magister Ilmu Manajemen, Universitas Muslim Indonesia, STIA Al Gazali, Barru \\ Email Korespondensi: 121111syamsiah@gmail.com
}

\begin{abstract}
Abstrak
Penelitian ini bertujuan untuk menganalisis pengaruh Capital Adequacy Ratio (CAR), Loan to Deposit Ratio (LDR), Biaya Operasional dan Pendapatan Operasional (BOPO) terhadap Return on Asset (ROA) pada Perbankan yang Terdaftar di Bursa Efek Indonesia. Jenis data yang digunakan adalah data sekunder yang berasal dari publikasi laporan keuangan Perusahaan Perbankan yang terdaftar di Bursa Efek Indonesia Periode Tahun 2017 - 2019. Teknik analisis data yang digunakan adalah analisis regresi linear berganda dengan bantuan Program SPSS versi 25. Hasil penelitian menunjukkan bahwa variabel Capital Adequacy Ratio (CAR) berpengaruh positif dan signifikan terhadap Return on Asset (ROA), variabel Loan to Deposit Ratio (LDR) berpengaruh negatif dan tidak signifikan terhadap Return on Asset (ROA), dan Biaya Operasional dan Pendapatan Operasional (BOPO) berpengaruh negatif dan signifikan terhadap Return on Asset (ROA).
\end{abstract}

Kata Kunci: CAR, LDR, BOPO, ROA

\section{Pendahuluan}

Perbankan Indonesia pernah menghadapi masa yang sangat sulit pada waktu krisis melanda pada tahun 1997. Semua indikator utama dalam perbankan menunjukkan kemerosotan yang sangat signifikan. Kondisi ini memang secara berangsur-angsur memang pulih dan kondisi sekarang ini bisa dikatakan sudah cukup baik, namun setelah mengeluarkan biaya yang tidak sedikit dari pengalaman masa lalu tersebut kita dapat belajar betapa pentingnya upaya untuk menjaga kestabilan perbankan dan kestabilan sistem keuangan secara keseluruhan. Krisis yang melanda indonesia tampaknya memberikan efek yang cukup berat termasuk bagi perbankan indonesia. Permodalan bank menjadi negatif, kredit perbankan dipenuhi oleh kredit dengan kualitas non performing, bank-bank mengalami kerugian yang tidak sedikit sehingga ROAnya menjadi negatif sementara sumber pendanaan pun mengalami penurunan.

Dalam pembicaraan sehari-hari, bank dikenal sebagai lembaga keuangan yang kegiatan utamanya menerima simpanan giro, tabungan dan deposito. Kemudian bank juga dikenal sebagai tempat untuk meminjam uang (kredit) bagi masyarakat yang membutuhkannya. Menurut UndangUndang RI Nomor 10 Tahun 1998 tanggal 10 November 1998 tentang Perbankan, yang dimaksud dengan Bank adalah "badan usaha yang menghimpun dana dari masyarakat dalam bentuk simpanan dan menyalurkannya kepada masyarakat dalam bentuk kredit dan atau bentuk-bentuk lainnya dalam rangka meningkatkan taraf hidup rakyat banyak."Dari pengertian tersebut dapat dijelaskan bahwa usaha perbankan meliputi tiga kegiatan utama yaitu menghimpun dana, menyalurkan dana, dan memberikan jasa bank lainnya. Pengertian menghimpun dana maksudnya adalah mengumpulkan atau mencari dana (uang) dengan cara membeli dari masyarakat luas dalam bentuk simpanan giro, tabungan, dan deposito. Kegiatan penghimpunan dana ini sering disebut dengan istilah funding. Strategi bank dalam menghimpun dana adalah dengan memberikan rangsangan berupa balas jasa yang menarik dan menguntungkan. Balas jasa tersebut dapat berupa bunga bagi bank yang berdasarkan prinsip konvensional dan bagi hasil bagi bank yang berdasarkan prinsip syariah. 
Saat ini perkembangan di dunia perbankan sangat pesat serta tingkat persaingan yang tinggi dapat berpengaruh terhadap performa suatu bank. Semakin maju suatu negara maka semakin besar peranan perbankan dalam mengendalikan negara tersebut. Adapun masalah yang ditimbulkan saat menjalankan usaha perbankan kredit macet hal ini dapat menyebabkan kinerja bank menurun. Dalam pemberian kredit bank dituntut agar dapat memperoleh keuntungan yang besar sehingga dapat menutupi semua biaya-biaya yang ditimbulkan dalam kegiatan operasionalnya. Sebagaimana layaknya manusia, dimana kesehatan merupakan hal yang paling penting didalam kehidupanya. Untuk menilai suatu kesehatan bank dapat dilihat dari berbagai segi. Penilaian ini bertujuan untuk menemukan apakah bank tersebut dalam kondisi yang sehat, cukup sehat, kurang sehat dan tidak sehat sehingga Bank Indonesia sebagai pengawas dan pembina bank-bank dapat memberikan arahan atau petunjuk bagaimana bank tersebut harus dijalankan atau bahkan dihentikan kegiatan operasinya. Beberapa penelitian menunjukkan bahwa rasio keuangan terbukti berperan dalam penilaian kinerja bank, termasuk risiko yang menyertai dalam kegiatan usaha bank.

Terdapat berbagai teknik analisis, salah satunya rasio keuangan yang dapatdipergunakan untuk melakukan penilaian kinerja suatu bank. Rasio-rasio yang bermanfaat dapat menunjukkan perubahan dalam kondisi keuangan atau kinerja operasi dan menggambarkan kecenderungan serta pola perubahan tersebut. Beberapa penelitian terdahulu menunjukkan bahwa rasio keuangan terbukti berperan dalam penilaian kinerja bank, termasuk risiko yang menyertai dalam kegiatan usaha tersebut. Salah satu komponen faktor permodalan adalah kecukupan modal. Rasio untuk menguji kecukupan modal bank yaitu rasio Capital Adequacy Ratio (CAR). Semakin efisien modal bank yang digunakan untuk aktivitas operasional mengakibatkan bank mampu meningkatkan pemberian kredit sehingga akan mengurangi tingkat risiko bank. Tingkat CAR sangat mempengaruhi kepercayaan masyarakat terhadap bank.

Loan to Deposit Ratio (LDR) adalah rasio yang digunakan mengukur komposisi jumlah kredit yang diberikan dibandingkan dengan jumlah dana masyarakat dan modal sendiri yang digunakan. Semakin tinggi LDR, maka semakin tinggi kredit diberikan. Semakin besar tingkat kredit yang diberikan, semakin meningkatkan potensi risiko kredit (gagal bayar) dan apabila LDR terlalu tinggi, bank justru dapat mengalami permasalahan berupa kesulitan likuiditas (Kasmir, 2014:225). Biaya Operasional dan Pendapatan Operasional (BOPO) digunakan untuk mengukur tingkat efesiensi dan kemampuan bank dalam melakukan kegiatan operasinya. Mengingat kegiatan utama bank pada prinsipnya adalah bertindak sebagai perantara, yaitu menghimpun dan menyalurkan dana (misalnya dana masyarakat), maka biaya dan pendapatan operasional bank didominasi oleh biaya bunga dan hasil bunga. Alasan dipilihnya Return On Asset (ROA) sebagai variabel terikat karena ROA merupakan rasio yang menunjukkan kinerja suatu bank. Dengan kata lain rasio ini digunakan untuk mengukur kemampuan manajemen bank dalam memperoleh keuntungan (laba) secara keseluruhan.

Menurut data yang diperoleh dari Statistik Perbankan Indonesia yang bersumber dari Otoritas Jasa Keuangan (OJK), sampai saat ini ada 110 bank umum yang terdaftar dengan jumlah kantor bank (unit) 31.127 dan 1.545 bank perkreditan rakyat dengan 5.939 kantor bank (unit). Jumlah bank umum dari tahun 2017 sampai tahun 2019 mengalami penurunan yaitu dari 115 bank menjadi 110 bank, begitu juga dengan jumlah kantor (unit) mengalami penurunan dari tahun 2017 sampai 2019 yaitu dari 32.276 menjadi 31.127 kantor (unit). Hal ini juga terjadi pada jumlah Bank Perkreditan Rakyat dari tahun 2017 sampai 2019 mengalami penurunan dari 1.619 bank menjadi 1.545 bank jumlah kantor Bank Perkreditan Rakyat juga mengalami penurunan dari tahun 2017 sampai tahun 2019 yaitu dari 6.192 menjadi 5.939 kantor (unit). Sejak tahun 2009, persaingan antar Bank Umum semakin ketat, ini membuat Bank Umum untuk meningkatkan kinerja agar dapat menarik investor. Investor sebelum menginvestasikan dananya di Bank Umum tentunya memerlukan informasi mengenai kinerja bank. Penggunaan laporan keuangan membutuhkan informasi yang dapat dipahami, dimengerti, relevan, andal serta dapat dibandingkan dalam mengevaluasi posisi keuangan dan kinerja suatu bank serta berguna dalam pengambilan keputusan.

Pada tahun 2016, secara umum industri perbankan nasional masih terjaga baik, hal ini dapat dilihat dari Laporan Perkembangan Industri Perbankan tahun 2016 yang bersumber dari Bank Indonesia, menunjukkan perkembangan rasio keuangan industri perbankan berfluktuasi. Rasio CAR mengalami peningkatan selama tiga tahun yaitu pada tahun 2014-2016 yaitu berturut-turut 19,57\%, $21,39 \%$ dan $22,93 \%$. Sementara itu rasio LDR berfluktuasi pada tahun 2014 nilai LDR sebesar 89,42\% naik pada tahun 2015 yaitu sebesar 92,11\% akan tetapi pada tahun 2016 mengalami penurunan, nilai 
LDR sebesar 90,70\%. Dilihat pada rasio BOPO selama tahun 2014-2016 mengalami kenaikan yaitu berturut-turut sebesar 76,29\%, 81,49\%, dan 82,22\%. Selama tahun 2014-2016 mengalami penurunan yaitu pada tahun 2014 nilai ROA sebesar 2,85\%, turun pada tahun 2015 menjadi 2,32\% dan pada tahun 2016 turun menjadi 2,23\%. Meskipun ROA mengalami penurunan akan tetapi masih sesuai dengan ketentuan Bank Indonesia yaitu batas minimun ROA sebesar 1,5\%.

Tingkat kesehatan suatu Bank Umum dapat dinilai dari beberapa indikator. Salah satu indikator utama yang dijadikan dasar penilaian adalah laporan keuangan yang bersangkutan. Berdasarkan laporan keuangan akan dapat dihitung sejumlah rasio-rasio keuangan yang lazim dijadikan penilaian tingkat kesehatan suatu bank umum. Dalam perbankan biasanya untuk menilai kinerja menggunakan lima aspek penting penilaian (sesuai peraturan Bank Indonesia) yaitu CAMELS (Capital, Asset, Management, Earning, Liquidity). Aspek Capital meliputi Capital Adequacy Ratio (CAR), aspek asset meliputi Non Performing Loan (NPL), aspek earning meliputi Net Interest Margin Ratio (NIM) dan Biaya Operasional dan Pendapatan Operasional (BOPO), sedangkan aspek liquiditas meliputi Loan To Deposit Ratio (LDR dan Giro wajib Minimum (GWM) (Jurnal Riset bisnis dan Manajemen : 2016 hal. 68).

Menurut Ni Kadek Nita Diantini (2020) Capital Adequacy Ratio (CAR) berpengaruh positif dan signifikan terhadap Kinerja Keuangan (ROA), BOPO berpengaruh negatif dan signifikan terhadap kinerja keuangan (ROA) dan Loan to Deposit Ratio (LDR) berpengaruh negatif dan signifikan terhadap kinerja keuangan (ROA). Sedangkan pada penelitian yang dilakukan oleh Apriliana, dkk (2019) rasio Loan to deposit Ratio (LDR) berpengaruh positif dan signifikan terhadap ROA. Sejak awal tahun 2000an gejala-gejala krisis ekonomi dunia sudah mulai nampak dengan melonjaknya harga minyak dunia, juga ditandai dengan meningkatnya suku bunga kredit (pinjaman) dan rendahnya daya beli masyarakat secaranasional di indonesia. Kondisi ini tentu saja memiliki dampak negatif terhadap pendapatan (laba) dunia perbankan.

Beberapa penelitian terdahulu menunjukkan adanya faktor-faktor yang mempengaruhi Return On Asset (ROA). Untuk itu peneliti tertarik untuk meneliti lebih lanjut tentang pengaruh Capital Adequacy Ratio (CAR), Loan to Deposit Ratio (LDR), Biaya Operasional dan Pendapatan Operasional (BOPO) terhadap Return On Asset (ROA) pada perbankan yang terdaftar di Bursa Efek Indonesia. Alasan meneliti pada perbankan adalah karena tingkat kinerja pada perbankan memiliki pengaruh yang kuat terhadap perekonomian di Indonesia dan kesejahteraan masyarakat dimasa yang akan datang. Dari beberapa pertimbangan diatas, alasan penulis memilih judul ini karena melihat tren kasus pada industri perbankan nasional adalah pada aspek Return On Asset (ROA) suatu bank. ROA digunakan untuk mengukur kemampuan manajemen bank dalam memperoleh keuntungan secara keseluruhan. Hal itu mendorong pemerintah RI untuk fokus terhadap peningkatan laba bagi industri perbankan agar terhindar dari masalah-masalah likuiditas

Tabel 1. Rumusan dan Tujuan Penelitian

1. Apakah Capital Adequancy Ratio (CAR) 1 1. Menganalisis pengaruh Capital Adequancy berpengaruh terhadap Return On Asset (ROA) Ratio (CAR) berpengaruh terhadap Return On pada perbankan yang terdaftar di Bursa Efek Indonesia (BEI) ?

2. Apakah Loan to Deposit Ratio (LDR) berpengaruh terhadap Return On Asset (ROA) pada perbankan yang terdaftar di Bursa Efek Indonesia (BEI) ?

3. Apakah Biaya Operasional Pendapatan Operasional (BOPO) berpengaruh terhadap Return On Asset (ROA) pada perbankan yang terdaftar di Bursa Efek Indonesia (BEI) ? asset (ROA) pada perbankan yang terdaftar di Bursa Efek Indonesia (BEI).

2. Menganalisis pengaruh Loan to Deposit Ratio (LDR) terhadap Return On asset (ROA) pada perbankan yang terdaftar di Bursa Efek Indonesia (BEI).

3. Menganalisis pengaruh Beban Operasional dan Pendapatan Operasional (BOPO) terhadap Return On asset (ROA) pada perbankan yang terdaftar di Bursa Efek Indonesia (BEI).

\section{Tinjauan Pustaka}

\section{A. Kerangka Konseptual}

Kerangka konseptual yang merupakan hubungan dari ketiga variabel tersebut yaitu kehandalan, ketanggapan dan empati, sebagai berikut. 


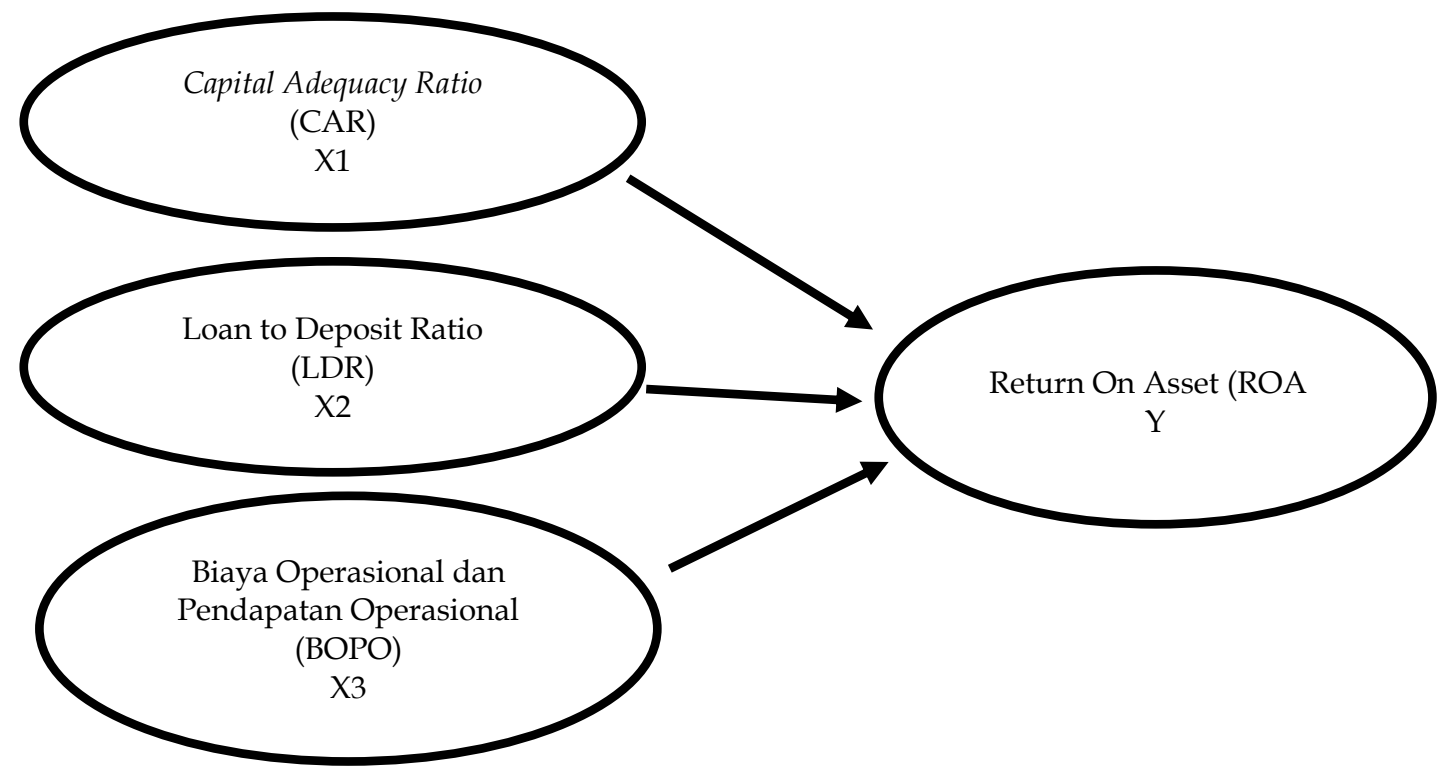

\section{Gambar 1. Kerangka Konseptual}

Berdasarkan rumusan masalah dan kerangka konseptual tersebut di atas, maka hipotesis yang diajukan dalam penelitian ini adalah sebagai berikut:

1. Capital Adequacy Ratio (CAR) berpengaruh positif dan signifikan terhadap Kinerja Keuangan perbankan.

2. Loan to Deposit Ratio (LDR) berpengaruh positif dan signifikan terhadap Kinerja Keuangan perbankan.

3. Biaya Operasional terhadap Pendapatan Operasional berpengaruh negatif dan signifikan terhadap Kinerja Keuangan perbankan.

\section{Metode Penelitian}

Penelitian ini diklasifikasikan sebagai jenis penelitian asosiatif kausalitas. Penelitian asosiatif kausalitas merupakan penelitian yang bertujuan untuk mengetahui hubungan sebab akibat antara dua variabel atau lebih, yaitu variabel independen atau variabel bebas terhadap variabel dependen atau variabel terikat (Sugiyono, 2012). Dalam penelitian ini variabel Independennya adalah CAR, LDR, dan BOPO sedangkan variabel dependennya adalah kinerja keuangan yang dalam penelitian ini diwakili oleh rasio Return on Asset (ROA). Penelitian ini dikategorikan sebagai penelitian kuantitatif. Suatu pendekatan kuantitatif apabila data yang dikumpulkan berupa data kuantitatif atau jenis data lain yang dapat dikuantitatifkan dan diolah dengan menggunakan teknik statistik. Penelitian ini dilakukan dengan melakukan akses internet terhadap beberapa situs, yaitu www.idx.co.id (situs dari Bursa Efek Indonesia), www.bi.go.id (situs dari Bank Indonesia), website dari masing-masing bank. Waktu penelitian akan direncanakan selama kurang lebih tiga bulan yaitu pada bulan Desember sampai Februari 2020. Dalam penelitian ini jenis data yang digunakan adalah data kuantitatif yaitu data berupa laporan keuangan perusahaan. Sedangkan sumber data yang digunakan dalam penelitian ini adalah data sekunder. Data sekunder merupakan sumber data yang diperoleh secara tidak lansung melalui media perantara atau diperoleh dan dicatat oleh pihak lain. Data sekunder umumnya berupa bukti, catatan yang telah tersusun dalam arsip (data dokumenter) yang dipublikasikan. Sumber data yang dibutuhkan diambil dari laman www.idx.co.id dan beberapa web terkait, serta literatur lainnya yang berkaitan dengan dengan penelitian ini. Untuk mengumpulkan data yang diperlukan sehubungan dengan penelitian ini, penulis menggunakan metode pengumpulan data dengan cara mengambil datadata dari catatan, dokumentasi, administrasi yang sesuai dengan data yang dibutuhkan melalui referensi dan buku literatur yang berkaitan dengan penelitian ini, serta dari website abursa Efek Indonesi (www.idx.co.id). Populasi adalah wilayah generalisasi yang terdiri atas objek/subjek yang mempunyai kualitas dan karakteristik tertentu yang ditetapkan oleh peneliti untuk dipelajari kemudian ditarik kesimpulan (Sugiyono, 2012). Adapun populasi dalam penelitian ini adalah semua perbankan yang tercatat di Bursa Efek Indonesia (BEI). Menurut data dari IDX bahwa jumlah bank yang tercatat 
di Bursa Efek Indonesi (BEI) sebanyak 44 perusahaan. Untuk lebih jelasnya akan disajikan pada tabei 2 sebagai berikut:

Tabel. 2. Daftar Bank yang terdaftar di BEI

\begin{tabular}{|c|c|c|c|}
\hline No & Kode Saham & Nama Emiten & Tanggal IPO \\
\hline 1 & AGRO & Bank Rakyat Indonesia Agro Niaga Tbk & 8-Agu-2003 \\
\hline 2 & AGRS & Bank IBK Indonesia Tbk & 22 Des- 2014 \\
\hline 3 & AMAR & Bank Amar Indonesia Tbk & 9-Jan-2020 \\
\hline 4 & ARTO & Bank Artos Indonesia Tbk & 12-Jan-2016 \\
\hline 5 & BABP & Bank MNC Internasional Tbk & 5-Jul-2002 \\
\hline 6 & $\overline{\mathrm{BACA}}$ & Bank Capital Indonesia Tbk & 8-Oct-2007 \\
\hline 7 & BBCA & Bank Central Asia Tbk & 31-May-2000 \\
\hline 8 & BBHI & Bank Harda Internasional Tbk & 12-Agu-2015 \\
\hline 9 & BBKP & Bank Bukopin Tbk & 10-Jul-2006 \\
\hline 10 & BBMD & Bank Mestika Dharma Tbk & 8-Jul-2013 \\
\hline 11 & BBNI & Bank Negara Indonesia (Persero) Tbk & 25-Nov-1996 \\
\hline 12 & BBRI & Bank Rakyat Indonesia (Persero) Tbk & 10-Nov-2003 \\
\hline 13 & BBTN & Bank Tabungan Negara (Persero) Tbk & 17-Dec-2009 \\
\hline 14 & BBYB & Bank Yudha Bakti Tbk & 13-Jan-2015 \\
\hline 15 & BCIC & Bank J Trust Indonesia Tbk & 25-Jul-1997 \\
\hline 16 & BDMN & Bank Danamon Indonesia Tbk & 6-Dec1989 \\
\hline 17 & BEKS & Bank Pembangunan Daerah Banten Tbk & 13-Jul-2001 \\
\hline 18 & BGTB & Bank Ganesha Tbk & 12-Mei-2016 \\
\hline 19 & BINA & Bank Ina Perdana Tbk & 16-Jan-2014 \\
\hline 20 & BJBR & Bank Pembangunan Daerah Jawa Barat Tbk & 8-Jul-2010 \\
\hline 21 & BJTM & Bank Pembangunan Daerah Jawa Timur Tbk & 12-Jul-2012 \\
\hline 22 & BKSW & Bank QNB Indonesia Tbk & 21-Nov-2020 \\
\hline 23 & BMAS & Bank Maspion Indonesia Tbk & 11-Jul-2013 \\
\hline 24 & BMRI & Bank Mandiri (Persero) Tbk & 14-Jul-2003 \\
\hline 25 & BNBA & Bank Bumi Arta Tbk & 31-Dec-1999 \\
\hline 26 & BNGA & Bank CIMB Niaga Tbk & 29-Nov-1989 \\
\hline 27 & BNII & Bank Maybank Indonesia Tbk & 21-Nov-1989 \\
\hline 28 & BNLI & Bank Permata Tbk & 15-Jan-1990 \\
\hline 29 & BRIS & Bank BRI Syariah & 09-Mei-2018 \\
\hline 30 & BSIM & Bank Sinar Mas Tbk & 13-Des-2010 \\
\hline 31 & BSWD & Bank of India Indonesia Tbk & 01-May-2002 \\
\hline 32 & BTPN & Bank BTPN Tbk & 12-Mar-2008 \\
\hline 33 & BTPS & Bank Tabunan Pensiunan Nasional Syariah Tbk & 08-Mei-2018 \\
\hline 34 & BVIC & Bank Victoria Internasional Tbk & 30-Jun-1999 \\
\hline 35 & DNAR & Bank Oke Indonesia Tbk & 11-Jul-2014 \\
\hline 36 & INPC & Bank Artha Graha Internasional Tbk & 29-Agu-1990 \\
\hline 37 & MAYA & Bank Mayapada Internasional Tbk & 29-Agu-1997 \\
\hline 38 & MCOR & Bank China Constructional Tbk & 03-Jul-2007 \\
\hline 39 & MEGA & Bank Mega Tbk & 17-Apr-2000 \\
\hline 40 & NISP & Bank OCBC NISP Tbk & 20-Oct-1994 \\
\hline 41 & NOBU & Bank Nationalobu Tbk & 20-Mei-2013 \\
\hline 42 & PNBN & Bank Pan Indonesia Tbk & 29-Des-1982 \\
\hline 43 & PNBS & Bank Panin Syariah Tbk & 15-Jan-2014 \\
\hline 44 & SDRA & Bank Woori Saudara Indonesia 1906 Tbk & 15-Dec-2006 \\
\hline
\end{tabular}

Sumber: $\underline{\text { www.idx.co.id }}$

Sedangkan Sampel adalah bagian dari jumlah dan karakteristik yang dimiliki oleh populasi tersebut (Sugiyono, 2012). Teknik pengambilan sampel dalam penelitian ini menggunakan metode purposive sampling, yaitu pengambilan sampel berdasarkan kriteria tertentu. Dalam penelitian ini sampel harus memenuhi kriteria-kriteria sebagai berikut: 
a. Perusahaan perbankan yang terdaftar di Bursa Efek Indonesia selama periode penelitian (20172019).

b. Tanggal pencatatan Listing saham atau IPO (Initial Public Offering) minimal pada tahun 2012.

c. Perusahaan perbankan yang mempublikasikan laporan keuangannya dalam Annual report secara berturut-turut selama periode penelitian pada website resminya.

d. Ketersediaan dan kelengkapan data yang diperlukan selama penelitian yaitu CAR, LDR, BOPO, dan ROA.

Tabel 3. Proses Pemilihan Sampel

\begin{tabular}{|c|l|c|}
\hline NO & \multicolumn{1}{|c|}{ KETERANGAN } & JUMLAH \\
\hline 1 & $\begin{array}{l}\text { Perusahaan perbankan yang terdaftar di Bursa Efek Indonesia selama tahun 2015- } \\
2019\end{array}$ & 44 \\
\hline 2 & $\begin{array}{l}\text { Tanggal pencatatan Listing saham atau IPO (Initial Public Offering) minimal pada } \\
\text { tahun 2012. }\end{array}$ & 30 \\
\hline 3 & $\begin{array}{l}\text { Perusahaan perbankan yang mempublikasikan laporan keuangan dalam Annual } \\
\text { report secara berturut-turut selama periode penelitian pada website resminya. }\end{array}$ & 25 \\
\hline 4 & $\begin{array}{l}\text { Ketersediaan dan kelengkapan data yang diperlukan selama penelitian yaitu CAR, } \\
\text { LDR, BOPO, dan ROA. }\end{array}$ & 19 \\
\hline 5 & Perusahaan Perbankan yang dijadikan sampel & 19 \\
\hline
\end{tabular}

Berdasarkan kriteria tersebut diatas maka ada 19 perusahaan perbankan yang dijadikan sampel adalah sebagai berikut:

Tabel 4. Daftar Nama Bank yang dijadikan Sampel Penelitian

\begin{tabular}{|c|c|c|}
\hline No & Nama Bank & Kode Emiten \\
\hline 1. & Bank Rakyat Indonesia Agro Niaga Tbk & AGRO \\
\hline 2. & Bank Central Asia Tbk & BBCA \\
\hline 3. & Bank Bukopin Tbk & BBKP \\
\hline 4. & Bank Negara Indonesia (Persero) Tbk & BBNI \\
\hline 5. & Bank Rakyat Indonesia (Persero) Tbk & BBRI \\
\hline 6. & Bank Tabungan Negara (Persero) Tbk & BBTN \\
\hline 7. & Bank Danamon Indonesia Tbk & BDMN \\
\hline 8. & Bank CIMB Tbk & BNGA \\
\hline 9. & Bank Maybank Indonesia Tbk & BNII \\
\hline 10. & Bank Permata Tbk & BNLI \\
\hline 11. & Bank Sinar Mas Tbk & BSIM \\
\hline 12. & Bank Of India Indonesia Tbk & BSWD \\
\hline 13. & Bank BTPN Tbk & BTPN \\
\hline 14. & Bank Victoria Internasional Tbk & BIVC \\
\hline 15. & Bank Mayapada Internasional Tbk & MAYA \\
\hline 16. & Bank China Contructional Tbk & MCOR \\
\hline 17. & Bank Mega Tbk & MEGA \\
\hline 18. & Bank Nationalabu Tbk & NOBU \\
\hline 19. & Bank Woori Saudara Indonesia Tbk & SDRA \\
\hline
\end{tabular}

Sumber: $\underline{w w w . i d x . c o . i d}$

Penelitian ini menggunakan analisis data linear berganda . teknik ini digunakan untuk mengetahui hubungan dan seberapa besar pengaruh dari variabel-variabel independen terhadap variabel dependen. Metode regresi yang digunakan adalah:

1. Analisis Statistik Deskriptif

Analisis statistik deskriptif merupakan analisis yang berdasarkan pada data yang telah dikumpulkan, kemudian data tersebut dianalisis dengan menghitung jumlah rata-rata, median, nilai minimum, dan nilai maksimum. Hasil dari analis digunakan untuk memberikan deskripsi atas variabelvariabel penelitian. 


\section{Uji Asumsi Klasik}

\section{a. Uji Normalitas}

Uji normalitas bertujuan untuk menguji apakah model regresi, variabel pengganggu atau residual memiliki distribusi normal. Uji normalitas digunakan untuk mengetahui suatu data dapat dilakukan dengan analisis grafik. Salah satu cara termudah untuk melihat normalitas residual adalah dengan melihat histogram dan normal probability plot yang membandingkan distribusi kumulatif dari data sesungguhnya dengan distribusi kumulatif dari distribusi normal. Jika distribusi data data residual normal, maka garis yang menggambarkan data sesungguhnya akan mengikuti garis diagonalnya. Metode yang dipakai untuk mengetahui model regresi adalah One Sample Kolmogorov-Smirnov Test dan Normal P-Plot. Distribusi data dinyatakan normal apabila nilai p dari One Sample KolmogorovSmirnov Test $>0.05$ dan sebaliknya. Sedangkan Normal Probability Plot of Regression Standarized residual apabila data menyebar disekitar garis diagonal atau mengikuti garis diagonal, maka model regresi memenuhi asumsi normalitas. Pada prinsipnya normalitas dapat dideteksi dengan melihat penyebaran data (titik) pada sumbu diagonal dari grafik atau dengan melihat histogrm dari residualnya. Dasar pengambilan keputusannya:

a) Jika data menyebar disekitar garis diagonal dan mengikuti arah garis diagonal atau grafik histogramnya menunjukkan pola distribusi normal, maka model regresi memenuhi asumsi normalitas.

b) Jika data menyebar jauh dari garis diagonal dan tidak mengikuti arah garis diagonal atau grafik histogramnya tidak menunjukkan pola distribusi normal, maka model regresi tidak mempengaruhi asumsi normalitas. Selain itu, untuk menguji normalitas data dapat digunakan uji statistik Kolmogorov Smirnov (K-S) yang dilakukan dengan membuat hipotesis nol ( $\mathrm{H} 0)$ untuk data berdistribusi normal dan hipotesis alternatif $(\mathrm{Ha})$ untuk data berdistribusi tidak normal. Dengan uji statistik yaitu dengan menggunakan uji statistik non-parametrik Kolmogrov-Smirnov. Hipotesis yang dikemukakan:

c) $\mathrm{H} 0=$ data residusl berdistribusi normal (Asymp. Sig $>0,05$ )

d) $\mathrm{Ha}=$ data residual tidak berdistribusi normal (Asymp. Sig <0,05)

\section{b. Uji Multikolinieritas}

Multikolinieritas adalah adanya suatu hubungan linear yang sempurna antara antara beberapa atau semua variabel independen. Uji multikolinieritas bertujuan untuk menguji apakah model regresi ditemukan adanya korelasi antar variabel bebas (independen). Model regresi yang baik seharusnya tidak terjadi korelasi diantara variabel Independen. Jika variabel independen saling berkorelasi, maka variabel-variabel ini tidak orthogonal. Variabel orthogonal variabel independen yang nilai korelasi antar sesama variabel independen yang nilai korelasi antar sesama variabel independen sama dengan nol. Multikorelasi dideteksi dengan menggunakan nilai tolerance dan variance inflasion factor (VIF). Kedua ukuran ini menunjukkan setiap variabel independen manakah yang dijelaskan oleh variabel independen lainnya. Nilai tolerance yang rendah sama dengan nilai VIF tinggi (karena VIF = 1 Tolerance). Nilai cut-off yang umum dipakai untuk menunjukkan adanya nilai Tolerance $\leq 0,10$ atau sama dengan VIF $\geq 10$.

\section{c. Uji Heteroskedastisitas}

Uji heteroskedastisitas dalam penelitian ini dimaksudkan untuk menguji apakah dalam model regresi terjadi ketidaksamaan varians residual suatu pengamatan ke pengamatan lain. Dalam regresi salah satu asumsi yang harus dipenuhi adalah bahwa varians dari residual satu pengamatan ke pengamatan lain tidak memiliki pola tertentu. Pola yang tidak sama ini ditunjukkan dengan nilai yang tidak sama antara satu varians dari residual yang disebut heteroskedastisitas. Sedangkan adanya gejala varians residual yang sama dari satu pengamatan ke pengamatan lain disebut homokedastisitas. Uji heteroskedastisitas dapat diketahui dengan melihat plot graik atau hubungan antara variabel terkait dengan nilai residualnya. Heteroskedastisitas akan muncul apabila terdapat pola tertentu antar keduanya seperti bergelombang dari kontinyu atau menyempit atau melebar teratur, sedangkan homokedastisitas akan muncul apabila tidak diperoleh pola yang jelas atau titik-titik yang diperoleh 
menyebar di atas dan di bawah angka 0 pada sumbu $Y$, sehingga tidak menghasilkan parameter bias yang menyebabkan kesalahan dalam perlakuannya.

\section{d. Uji Autokorelasi}

Uji Autokorelasi bertujuan menguji apakah dalam suatu model regresi linear ada korelasi antara kesalahan pengganggu pada periode $t$ dengan kesalahan pada periode $t-1$ (sebelumnya). Autokorelasi muncul karena observasi yang berurutan sepanjang waktu berkaitan satu sama lain. Model regresi yang baik adalah regresi yang bebas dari autokorelasi. Pengujian penyimpangan autokorelasi dalam penelitian dengan menggunakan Durbin Watson Test (DW-test).

3. Uji Hipotesis

a. Uji Analisis Regresi Berganda

Setelah melalui uji asumsi klasik, maka data yang sudah dikumpulkan tersebut dianalisa dengan menggunakan metode regresi linear berganda. Analisis regresi adalah studi mengenai ketergantungan variabel dependen dengan satu atau lebih variabel independen untuk memprediksi nilai rata-rata populasi atau nilai rata-rata variabel dependen berdasarkan nilai variabel independen yang diketahui. Dalam analisis regresi, selain mengukur kekuatan hubungan antara dua variabel atau leih, juga menunjukkan arah hubungan antara variabel dependen dengan independen. Adapun metode dasarnya dapat dirumuskan sebagai berikut:

Keterangan:

$$
\mathrm{Y}=\mathrm{a}+\mathrm{b} 1 \mathrm{X} 1+\mathrm{b} 2 \mathrm{X} 2+\mathrm{b} 3 \mathrm{X} 3+\mathrm{e}
$$

$$
\begin{array}{ll}
\mathrm{Y} & =\text { Return on Asset (ROA) } \\
\mathrm{a} & =\text { Konstanta persamaan regresi } \\
\mathrm{X} 1 & =\text { Capital Adequacy Ratio (CAR) } \\
\mathrm{X} 2 & =\text { Loan to Deposit Ratio (LDR) } \\
\mathrm{X} 3 & =\text { Biaya Operasioanal terhadap Pendapatan Operasional (BOPO) } \\
\mathrm{b} & =\text { Koefisien regresi untuk mengukur besarnya pengaruh X terhadap Y } \\
\mathrm{e} & =\text { Variabel pengganggu atau faktor-faktor diluar variabel yang tidak dimasukkan } \\
& \text { sebagai variabel model diatas (kesalahan residual). }
\end{array}
$$

b. Uji Koefisien Determinasi (R2)

Koefisien determinasi menjelaskan variasi pengaruh variabel-variabel bebas terhadap variabel terikatnya. Atau dapat pula dikatakan sebagai proporsi pengaruh seluruh variabel bebas terhadap variabel terikat. Pada model regresi linear beganda ini, akan dilihat besarnya konstribusi untuk variabel bebas terhadap variabel terikatnya dengan melihat besarnya koefisien determinasi totalnya (R2). Jika R2 yang diperoleh mendekati 1 maka dapat dikatakan semakin kuat model tersebut menerangkan hubungan variabel bebas terhadap variabel terikat. Sebaliknya jika R2 makin mendekati 0 (nol) maka semakin lemah pengaruh variabel bebas terhadap variabel terikat..

c. Uji T (Uji Parsial)

Uji ini digunakan untuk mengetahui signifikansi dari pengaruh variabel independen terhadap variabel dependen secara individual dan menganggap dependen yang lain konstan. Signifikansi pengaruh tersebut dapat diestimasi dengan membandingkan antara nilai t-tabel dengan nilai t-hitung. Apabila nilai t-hitung $>\mathrm{t}$-tabel maka variabel independen secara individual memengaruhi variabel dependen, sebaliknya jika nilai $\mathrm{t}$-hitung $<\mathrm{t}$-tabel maka variabel independen secara individual tidak memengaruhi variabel dependen.

d. Uji F (Uji Serempak)

Uji ini digunakan untuk menguji secara bersama ada tidaknya pengaruh variabel bebas terhadap variabel terikat. Disebut uji F, karena mengikuti distribusi $\mathrm{F}$ yang kriteria pengujiannya seperti One Way Anova. Apabila nilai prob F hitung lebih kecil dari tingkat kesalahan/error (alpha) 0,05 maka dapat dikatakan bahwa model regresi yang determinasi 
layak. Sedangkan apabila nilai prob F hitung lebih besar dari tingkat kesalahan 0,05 maka dapat dikata

\section{Pembahasan}

\section{A. Hasil Penelitian}

\section{Deskripsi Variabel Penelitian}

Bank sebagai lembaga keuangan perbankan dengan usaha utamanya memberikan jasa dibidang perbankan. Perbankan menjalankan fungsinya berasaskan prinsip kehati-hatian. Fungsi utama perbankan adalah sebagai penghimpun dan penyalur dana masyarakat yang bertujuan untuk menunjang pelaksanaan pembangunan nasional dalam rangka meningkatkan pemerataan pembangunan dan hasil-hasilnya. Perbankan juga sebagai salah satu pilar pertumbuhan ekonomi dan stabilitas nasional untuk meningkatkan taraf hidup masyarakat dari sisi sektor keuangan. Kinerja keuangan perbankan adalah merupakan salah satu faktor terpenting karena menunjukkan efisien dan efektifnya suatu perbankan dalam pencapaian tujuan. Dengan demikian dalam menjaga kinerja keuangan perbankan maka terdapat sejumlah rasio yang perlu diperhatikan yaitu CAR, LDR, BOPO dan ROA. Dalam hubungannya dengan uraian tersebut diatas, maka disajikan analisis kinerja perbankan yaitu sebagai berikut :

Tabel 5. Data Rata-rata Rasio CAR, LDR, BOPO, dan ROA pada Perusahaan Perbankan yang Terdaftar di Bursa Efek Indonesia tahun 2017-2019

\begin{tabular}{|c|c|c|c|c|}
\hline \multirow{2}{*}{ No } & \multirow{2}{*}{ Variabel Penelitian } & 2017 & 2018 & 2019 \\
\cline { 3 - 5 } & & 27,78 & 21,56 & 21,66 \\
\hline 1 & CAR & 84,76 & 92,02 & 95,00 \\
\hline 2 & LDR & 84,56 & 83,94 & 87,36 \\
\hline 3 & BOPO & 1,89 & 1,72 & 1,51 \\
\hline 4 & ROA &
\end{tabular}

Sumber : Data diolah

Pada tabel 5 menunjukkan nilai rata-rata rasio CAR mengalami fluktuasi. Pada tahun 2018 nilai CAR turun dari tahun sebelumnya tahun 2017 sebesar $27,78 \%$ menjadi $21,56 \%$. Kemudian naik kembali pada tahun 2019 sebesar $21,66 \%$. Nilai CAR tertinggi terdapat pada tahun 2017 yaitu sebesar 27,78\% sedangkan nilai CAR terendah pada Tahun 2018 sebesar 21,56\%. Dilihat dari tabel di atas nilai CAR telah sesuai dengan Peraturan Bank Indonesia yaitu 8\%. Dengan demikian bank yang digunakan dalam penelitian ini memiliki kemampuan kecukupan modal yang mampu menutupi kemungkinan timbulnya risiko. Nilai rata-rata rasio LDR mengalami peningkatan dari tahun 2017-2019. Nilai LDR terus meningkat yaitu berturut-turut 84,76\%, 92,56\% dan 95,00\%. Nilai LDR tertinggi pada tahun 2019 sebesar 95,00\% sedangkan nilai terendah LDR pada tahun 2017 sebesar 84,76\%. Dari Tabel 6 di atas menunjukkan bahwa telah memenuhi ketetapan Bank Indonesia. Penting bagi pihak manajemen untuk memperhatikan rasio LDR tetap berada pada batas aman yang telah ditentukan oleh Bank Indonesia. Jika angka rasio LDR berada dibawah $78 \%$ maka dapat dikatakan bahwa bank tersebut tidak dapat menyalurkan kembali dengan baik seluruh dana yang telah dihimpun. Jika rasio LDR bank mencapai lebih dari 92\% maka total kredit yang disalurkan oleh bank tersebut telah melebihi dana yang dihimpun. Pengelolaan dana masyarakat ini, bank dituntut untuk mampu menjaga likuiditasnya agar tetap mendapatkan kepercayaan dari masyarakat. Besar kecilnya LDR suatu bank akan mempengaruhi profitabilitas bank tersebut. Nilai rata-rata rasio BOPO mengalami fluktuasi dari tahun 2017-2019. Pada tahun 2018 nilai BOPO turun dibandingkan pada tahun 2017 yaitu sebesar $84,56 \%$ menjadi $83,94 \%$, kemudian naik kembali pada tahun 2019 sebesar $87,36 \%$. Nilai BOPO tertinggi yaitu pada tahun 2019 sebesar 87,36\% sedangkan nilai BOPO terendah pada tahun 2018 sebesar $83,94 \%$. Dalam perbankan atau perusahaan, BOPO berpengaruh besar dalam mengukur tingkat efisiensi dan juga kemampuan bank dalam menjalanan kegiatan operasionalnya. Untuk itu setiap usaha harus melakukan perbandingan antara jumlah biaya operasional dan juga pendapatan operasonal yang diperolehnya. 
BOPO dapat melihat seberapa besar kemampuan perusahaan dalam mengelola beban operasionalnya. Makin bengkak beban operasional, berarti makin buruk pengelolaan perusahaan tersebut. Nilai rata-rata rasio ROA dari tahun 2017-2019 mengalami penurunan. Pada tahun 2017 nilai ROA sebesar 1,89\%, tahun 2018 sebesar 1,72\% dan pada tahun 2019 sebesar 1,51\%. Return on Asset digunakan untuk mengukur kemampuan manajemen bank dalam memperoleh keuntungan. Semakin besar ROA maka semakin tinggi pula tingkat keuntungan yang dicapai oleh bank. Return On Asset (ROA) diperoleh dengan cara membandingkan netincome terhadap total asset. Net Income merupakan pendapatan bersih sesudah pajak. Semakin besar ROA menunjukkan kinerja yang semakin baik, karena tingkat pengembalian yang semakin besar Standar terbaik ROA menurut Peraturan Bank Indonesia No.6/9/PBI/2004 adalah 1,5\%. Variabel ini mempunyai bobot nilai 15\%.

\section{Statistik Deskriptif}

\section{a. Uji Analisis Deskriptif}

Statistik deskriptif digunakan untuk menunjukkan jumlah data (N) yang digunakan dalam penelitian ini serta dapat menunjukkan nilai Maksimim, nilai Minimum, nilai rata-rata (mean) serta standar deviasi $(\delta)$ dari masing-masing variabel. Variabel penelitian ini terdiri dari variabel kecukupan modal yang diukur dengan menggunakan Capital Adequacy Ratio (CAR), variabel likuiditas yang diukur menggunakan Loan Deposit Ratio (LDR), variabel operasional diukur dengan menggunakan Biaya Operasional dan Pendapatan Operasional (BOPO), dan variabel kinerja keuangan yang diukur dengan menggunakan Return on Asset (ROA). Adapun hasil olahan statistik deskriptif data variabel dengan menggunakan SPSS dapat disajikan dalam tabel 6 berikut :

Tabel 6. Uji Analisis Deskriptif

\begin{tabular}{|l|c|c|c|c|c|c|c|}
\hline & $\mathrm{N}$ & Minimum & Maximum & \multicolumn{2}{|c|}{ Mean } & Std. Deviation & Variance \\
\cline { 2 - 8 } & Statistic & Statistic & Statistic & Statistic & Std. Error & Statistic & Statistic \\
\hline CAR & 57 & 10.52 & 45.85 & 21.4347 & .84079 & 6.34782 & 40.295 \\
\hline LDR & 57 & 51.67 & 163.10 & 90.3042 & 2.45014 & 18.49816 & 342.182 \\
\hline BOPO & 57 & 58.20 & 119.43 & 85.5568 & 1.68800 & 12.74414 & 162.413 \\
\hline ROA & 57 & .09 & 4.00 & 1.6665 & .15847 & 1.19641 & 1.431 \\
\hline $\begin{array}{l}\text { Valid N } \\
\text { (listwise) }\end{array}$ & 57 & & & & & & \\
\hline
\end{tabular}

Sumber: Data Sekunder (diolah) melalui SPSS 25, 2021

Pada tabel 6 diatas dapat diketahui jumlah pengamatan yang diteliti sebanyak 57 pengamatan, berdasarkan 19 bank dengan 3 tahun periode penelitian yaitu tahu 2017-2019. Nilai minimum CAR sebesar 10,52 dan nilai maksimum sebesar 45,85. Rata-rata nilai CAR sebesar 21,4347. Hal ini menandakan bahwa perbankan dalam penelitian ini telah memiliki kecukupan modal yang baik untuk menampung risiko kerugian bank yang mungkin terjadi. Pada tabel 6 menunjukkan nilai minimum dari rasio LDR sebesar 51,67 dan nilai maksimum sebesar 163,10. Nilai rata-rata rasio LDR sebesar 90.3042. Hal ini menunjukkan bahwa LDR telah memenuhi standar yang telah ditetapkan oleh Bank Indonesia. Pada tabel 6 menunjukkan nilai minimum BOPO sebesar 58,20 dan nilai maksimum rasio BOPO sebesar 119,43. Nilai rata-rata BOPO sebesar 85,5568. Hal ini menandakan bahwa nilai BOPO telah memenuhi standar yang telah ditetapkan oleh Bank Indonesia. Pada tabel 6 diatas dapat diketahui jumlah pengamatan yang diteliti sebanyak 57 pengamatan, berdasarkan 19 bank dengan 3 tahun periode penelitian yaitu tahu 2017-2019. Nilai rasio minimum Return on Asset (ROA) adalah sebesar 0,09 dan nilai maksimum adalah sebesar 4.00 dan serta nilai rata-rata ROA adalah sebesar 1.6665 dengan standar deviasi sebesar 1,19641

\section{b. Uji Asumsi Klasik}

1) Uji Normalitas

Uji normalitas bertujuan untuk menguji apakah model regresi, variabel pengganggu atau residual memiliki distribusi normal. Uji normalitas digunakan untuk mengetahui suatu data dapat dilakukan dengan analisis grafik. Metode yang dipakai untuk mengetahui model regresi adalah One Sample Kolmogorov-Smirnov Test dan Normal P-Plot. Distribusi data dinyatakan normal apabila nilai $p$ dari One Sample Kolmogorov-Smirnov Test > 0.05 dan sebaliknya. Sedangkan Normal Probability Plot of 
Regression Standarized residual apabila data menyebar disekitar garis diagonal atau mengikuti garis diagonal, maka model regresi memenuhi asumsi normalitas. Hasil Uji Normalitas pada penelitian ini dapat dilihat pada gambar 2 berikut ini:

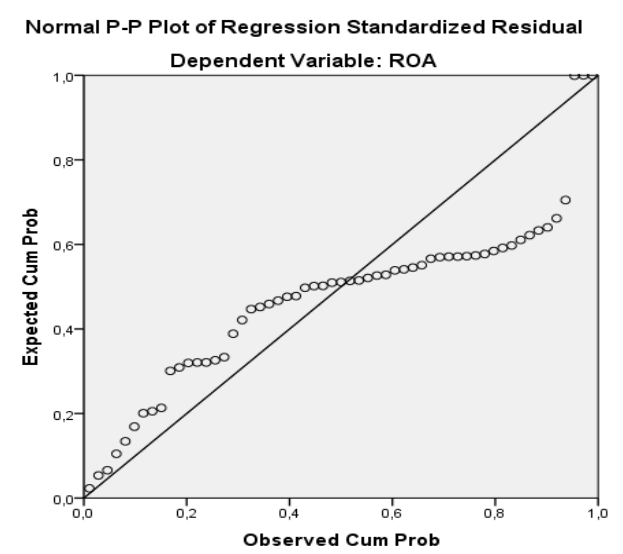

Gambar. 2 Normal P-Plot

Sumber : Data Sekunder (diolah) melalui SPSS 25,2021

Berdasarkan tampilan grafik Normal P-Plot diatas, dapat disimpulkan bahwa pola grafik normal terlihat dari titik-titik yang menyebar disekitar garis diagonal dan penyebarannya mengikuti arah garis diagonal. Berdasarkan grafik Normal P-Plot, menunjukkan bahwa model regresi layak dipakai dalam penelitian ini karena memenuhi asumsi normalitas. Uji asumsi kenormalan dapat juga dilihat dari histogram antara nilai Return on Asset (ROA) sebagai variabel dependen dengan Regression Standardized Residual, dimana dapat dilihat bahwa sebagian besar data memberikan pola distribusi normal (berbentuk lonceng), sehingga dapat dikatakan bahwa data yang dianalisis memenuhi syarat normalitas. Hasil olah data Uji Normalitas dapat dilihat pada Gambar 3 berikut :

Histogram

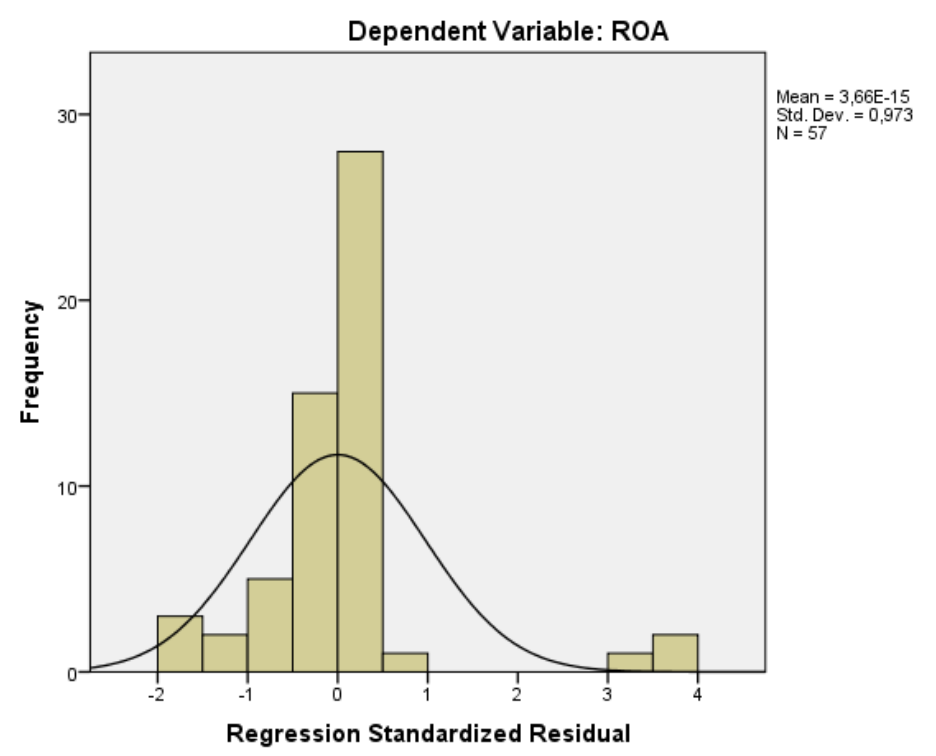

Gambar. 3 Histogram dan Regression Standardized Residual

Sumber : Data Sekunder (diolah) melalui SPSS 25, 2021

Berdasarkan tampilan histogram dari variabel CAR, LDR, BOPO dan ROA terlihat bahwa kurva dependen dan Regression Standardized Residual membentuk gambar seperti lonceng. Oleh karena itu berdasarkan uji normalitas, analisis regresi layak digunakan. Uji normalitas data dalam penelitian ini juga menggunakan uji Kolmogorov-Smirnov. Uji Kolmogorov-Smirnov menggunakan bantuan SPSS 
25 untuk mengetahui apakah data berdistribusi normal atau tidak dilihat pada baris Asymp. Sig (2tailed). Data penelitian dikatakan normal atau memenuhi uji normalitas apabila nilai Asymp. Sig (2tailed) variabel residual berada diatas 0,05 atau $5 \%$. Apabila berada dibawah 0,05 atau $5 \%$ data tersebut tidak terdistribusi normal atau tidak memenuhi uji normalitas. Uji normalitas yang dilakukan dengan uji K-S adalah sebagai berikut :

Tabel 7. Uji Normalitas (Kolmogorov-Smirnov)

\begin{tabular}{|l|l|r|}
\hline \multicolumn{2}{|l|}{ One-Sample Kolmogorov-Smirnov Test } & \multicolumn{1}{|c|}{ Unstandardized Residual } \\
\hline \multicolumn{2}{|l|}{ N } & Mean \\
\hline \multirow{2}{*}{ Normal Parametersa,b } &, 0000000 \\
\cline { 2 - 3 } & Std. Deviation &, 51573936 \\
\hline \multirow{2}{*}{ Most Extreme Differences } & Absolute &, 268 \\
\cline { 2 - 3 } & Positive &, 268 \\
\cline { 2 - 3 } & Negative &, 268 \\
\hline Test Statistic &, 090 \\
\hline Asymp. Sig. (2-tailed) & \\
\hline a. Test distribution is Normal. & \\
\hline b. Calculated from data. & & \\
\hline
\end{tabular}

Sumber : Data Sekunder (diolah) melalui SPSS 25, 2021

Berdasarkan hasil uji normalitas menggunakan Uji Kolmogorov-Smirnov, hasil pengolahan data menunjukkan bahwa data berdistribusi normal. Hal ini dibuktikan dengan hasil Uji K-S yang menunjukkan nilai Asymp. Sig (2-tailed) diatas tingkat signifikansi 0.050 yaitu sebesar 0.090.

\section{2) Uji Multikolonearitas}

Multikolinieritas adalah adanya suatu hubungan linear yang sempurna antara antara beberapa atau semua variabel independen. Uji multikolinieritas bertujuan untuk menguji apakah model regresi ditemukan adanya korelasi antar variabel bebas (independen). Model regresi yang baik seharusnya tidak terjadi korelasi diantara variabel Independen. Jika variabel independen saling berkorelasi, maka variabel-variabel ini tidak orthogonal. Variabel orthogonal variabel independen yang nilai korelasi antar sesama variabel independen yang nilai korelasi antar sesama variabel independen sama dengan nol. Multikorelasi dideteksi dengan menggunakan nilai tolerance dan variance inflasion factor (VIF). Kedua ukuran ini menunjukkan setiap variabel independen manakah yang dijelaskan oleh variabel independen lainnya. Nilai tolerance yang rendah sama dengan nilai VIF tinggi (karena VIF = 1 Tolerance). Nilai cut-off yang umum dipakai untuk menunjukkan adanya nilai Tolerance $\leq 0,10$ atau sama dengan VIF $\geq 10$.

Tabel 8. Uji Multikolonearitas

\begin{tabular}{|l|l|r|r|}
\hline \multicolumn{4}{|c|}{ Coefficients $^{\mathbf{3}}$} \\
\cline { 3 - 5 } \multirow{2}{*}{ Model } & \multicolumn{3}{|c|}{ Collinearity Statistics } \\
\hline \multirow{3}{*}{1} & (Constant) & & \multicolumn{1}{c|}{ VIF } \\
\cline { 2 - 5 } & CAR &, 971 & 1,030 \\
\cline { 2 - 5 } & LDR &, 984 & 1,016 \\
\cline { 2 - 5 } & BOPO &, 986 & 1,015 \\
\hline
\end{tabular}

Sumber : Data Sekunder (diolah) melalui SPSS 25, 2021

Pada tabel diatas maka dapat diketahui nilai VIF untuk masing-masing variabel penelitian sebagai berikut:

a. Nilai VIF CAR sebesar 1,030 dengan tolerance 0,971 yang dimana nilai VIF $<10$ dan tolerance $>0,01$, sehingga variabel CAR dinyatakan tidak terjadi gejala multikolinieritas.

b. Nilai VIF LDR sebesar 1,016 dengan tolerance 0,984 yang dimana nilai VIF $<10$ dan tolerance lebih dari >, sehingga variabel LDR dinyatakan tidak terjadi gejala multikolinieritas.

c. Nilai VIF BOPO sebesar 1,015 dengan tolerance 0,986 yang dimana nilai VIF $<10$ dan tolerance $>0,01$, sehingga variabel BOPO dinyatakan tidak terjadi gejala multikolinieritas. 


\section{3) Uji Autokorelasi}

Uji Autokorelasi bertujuan menguji apakah dalam suatu model regresi linear ada korelasi antara kesalahan pengganggu pada periode $t$ dengan kesalahan pada periode $t-1$ (sebelumnya). Autokorelasi muncul karena observasi yang berurutan sepanjang waktu berkaitan satu sama lain. Model regresi yang baik adalah regresi yang bebas dari autokorelasi. Pengujian penyimpangan autokorelasi dalam penelitian dengan menggunakan Durbin Watson Test (DW-test).

Tabel 9. Uji Autokorelasi dengan Durbin Watson Test (DW-test)

\begin{tabular}{|c|c|c|c|c|c|}
\hline \multicolumn{6}{|c|}{ Model Summary ${ }^{b}$} \\
\hline Model & $\mathrm{R}$ & R Square & $\begin{array}{l}\text { Adjusted R } \\
\text { Square }\end{array}$ & $\begin{array}{l}\text { Std. Error of the } \\
\text { Estimate }\end{array}$ & Durbin-Watson \\
\hline 1 & ,644a & ,414 & ,406 &, 53013 & 1,664 \\
\hline
\end{tabular}

Sumber : Data Sekunder (diolah) melalui SPSS 25, 2021

Berdasakan tabel 9 di atas maka diperoleh nilai DW (Durbin Waston) Hitung adalah1,664 nilai ini akan dibandingkan dengan nilai tabel signifikansi 0,05 dengan rumus $(\mathrm{K} ; \mathrm{N})$. Adapun Jumlah variabel Independen adalah 3 atau " $k$ " $=3$, sementara jumlah sampel atau " $N$ " $=57$, maka $(k ; N)=(3$; 57). Angka ini kemudian dilihat dari tabel Durbin waston, maka ditemukan nilai dL sebesar 1.4637 dan dU sebesar 1.6845. Nilai Durbin Waston (d) sebesar 1.568, nilai batas atas (dU) yaitu sebesar 1.6845 dan nilai 4-du $(4-1.6845)=2.3155$. Nilai Durbin Waston terletak antara dU dan 4-dU, maka tidak terjadi autokorelasi.

4) Uji Heterokedastisitas

Uji Heterokedastisitas adalah untuk menguji apakah dalam sebuah model regresi, terjadi ketidaksamaan varians residual dari satu pengamatan ke pengamatan yang lain. Jika varians residual satu pengamatan ke pengamatan lain tetap, maka disebut heterokedastisitas. Model regresi yang baik seharusnya tidak terjadi heterokedastisitas. Dasar pengambilan keputusan dalam uji heterokedastisitas dengan grafik Scatterplot yaitu:

a. Jika terdapat pola tertentu pada grafik Scatterplot, seperti titik yang membentuk pola teratur (bergelombang, menyebar kemudian menyempit) maka dapat disimpulkan bahwa telah terjadi heterokedastisitas.

b. Sebaliknya jika ada pola yang jelas serta titik-titik yang menyebar maka indikasinya adalahtidak terjadi heterokedastisitas.

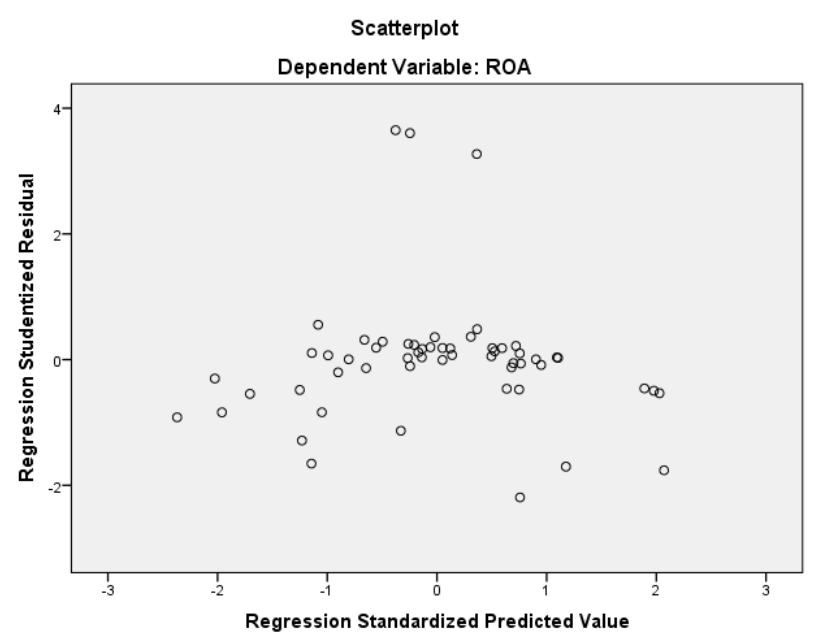

Gambar. 4 Uji Heterokedastisitas dengan Grafik Scatterplot

Sumber : Data Sekunder (diolah) melalui SPSS 25, 2021 
Berdasarkan grafik Scatterplot dibawah ini maka terlihat tidak adanya pola yang jelas serta adanya titik-titik yang menyebar disekitas sumbu X dan Y, maka dapat disimpulkan bahwa tidak terjadi heterokedastisitas.

\section{c. Uji Hipotesis}

\section{1) Regresi Linear Berganda}

Setelah dilakukan pengujian statistik deskriptif dan uji asumsi klasik, maka variabel-variabel penelitian ini akan dianalisis linear berganda. Analisis regresi adalah studi mengenai ketergantungan variabel dependen dengan satu atau lebih variabel independen untuk memprediksi nilai rata-rata populasi atau nilai rata-rata variabel dependen berdasarkan nilai variabel independen yang diketahui. Dalam analisis regresi, selain mengukur kekuatan hubungan antara dua variabel atau lebih, juga menunjukkan arah hubungan antara variabel dependen dengan independen. Dengan menggunakan SPSS 25 untuk mengetahui pengaruh variabel independen terhadap variabel dependen dapat dilihat melalui tabel berikut ini:

Tabel 10. Uji Regresi Linear Berganda

\begin{tabular}{|c|c|c|c|c|c|c|}
\hline \multicolumn{7}{|c|}{ Coefficients ${ }^{a}$} \\
\hline & & \multicolumn{2}{|c|}{ Unstandardized Coefficients } & \multirow{2}{*}{$\begin{array}{c}\text { Standardized } \\
\text { Coefficients } \\
\text { Beta } \\
\end{array}$} & \multirow[b]{2}{*}{$\mathrm{t}$} & \multirow[b]{2}{*}{ Sig. } \\
\hline & del & B & Std. Error & & & \\
\hline \multirow[t]{4}{*}{1} & (Constant) & 5,250 & 2,538 & & 2,069 &, 043 \\
\hline & CAR & 1,796 & 647 & ,325 & 2,777 & 008 \\
\hline & LDR &,- 357 & 492 &,- 084 &,- 725 & 472 \\
\hline & BOPO & $-3,503$ & 1,069 &,- 381 & $-3,277$ & 002 \\
\hline
\end{tabular}

Sumber : Data Sekunder (diolah) melalui SPSS 25, 2021

Hasil pengujian Regresi Linear Berganda dapat dilihat pada persamaan berikut:

$$
Y=5,250+1,796 X_{1}-0,357 X_{2}-3,503 X_{3}
$$

Dari persamaan regresi linear berganda di atas, diketahui bahwa nilai konstanta sebesar 5,250 berarti nilai CAR, LDR dan BOPO nilainya adalah nol, maka ROA nilainya 5,250. Variabel CAR memiliki nilai koefisien sebesar 1,796 yang berarti jika mengalami kenaikan sebesar 1 satuan, maka ROA naik sebesar 1,796 satuan dengan asumsi variabel lain dianggap konstan, dan menunjukkan hubungan positif (searah). Variabel LDR memiliki nilai koefisien sebesar $-0,357$ yang artinya jika variabel LDR mengalami kenaikan sebesar 1 satuan maka ROA turun sebesar -0,357 dan dengan asumsi variabel lain dianggap konstan dan menunjukkan hubungan yang berlawanan. Sedangkan variabel BOPO memiliki nilai koefisien sebesar $-3,503$ yang artinya jika variabel BOPO mengalami peningkatan sebesar 1 satuan maka ROA turun sebesar -3,503 dengan asumsi bahwa variabel lain dianggap konstan (menunjukkan hubungan berlawanan).

\section{2) Uji Koefisien Determinasi}

Koefisien Determinasi digunakan untuk mengetahui keeratan hubungan antara variabel bebas (CAR, LDR, BOPO) dengan variabel terikat (ROA). Tujuan menghitung koefisien determinasi adalah untuk mengetahui pengaruh variabel bebas dengan variabel terikat. Dari hasil analisis diperoleh koefisien korelasi $(\mathrm{R})$ menunjukkan adanya hubungan antara variabel $\mathrm{X}$ dengan variabel $\mathrm{Y}$. Hasil Uji Koefisien Determinasi adalah sebagai berikut: 


\begin{tabular}{|c|c|c|c|c|c|}
\hline Model & $\mathrm{R}$ & R Square & Adjusted R Square & $\begin{array}{l}\text { Std. Error of the } \\
\text { Estimate }\end{array}$ & Durbin-Watson \\
\hline 1 & $644^{a}$ & ,414 & ,406 &, 53013 & 1,664 \\
\hline \multicolumn{6}{|c|}{ a. Predictors: (Constant), BOPO, LDR, CAR } \\
\hline
\end{tabular}

Sumber : Data Sekunder (diolah) melalui SPSS 25, 2021

Dari hasil perhitungan koefisien korelasi (R) diperoleh sebesar 0.644 atau $64,4 \%$. hal ini berarti bahwa korelasi antara CAR, LDR, dan BOPO mempunyai hubungan yang kuat terhadap ROA. Sedangkan untuk mengetahui kontribusi variabel bebas dan variabel terikat digunakan ukuran koefisien determinasi $R^{2}$. Nilai determinasi $\left(R^{2}\right)$ sebesar 0.414 atau $41,4 \%$ yang artinya persentase sumbangan pengaruh variabel independen (CAR, LDR, dan BOPO) terhadap variabel dependen (ROA) sebesar $41,4 \%$ sedangkan sisanya sebesar $58,6 \%$ ditentukan oleh variabel lain diluar model regresi.

\section{3) Uji Serempak (Uji F)}

Uji ini digunakan untuk menguji secara bersama ada tidaknya pengaruh variabel bebas terhadap variabel terikat.pedoman yang digunakan apabila koefisien signifikan $>0.05$, maka tidak ada pengaruh signifikan sedangkan apabila koefisien signifikan $<0.05$ maka ada pengaruh signifikan.

Tabel 12. Uji Serempak (Uji F)

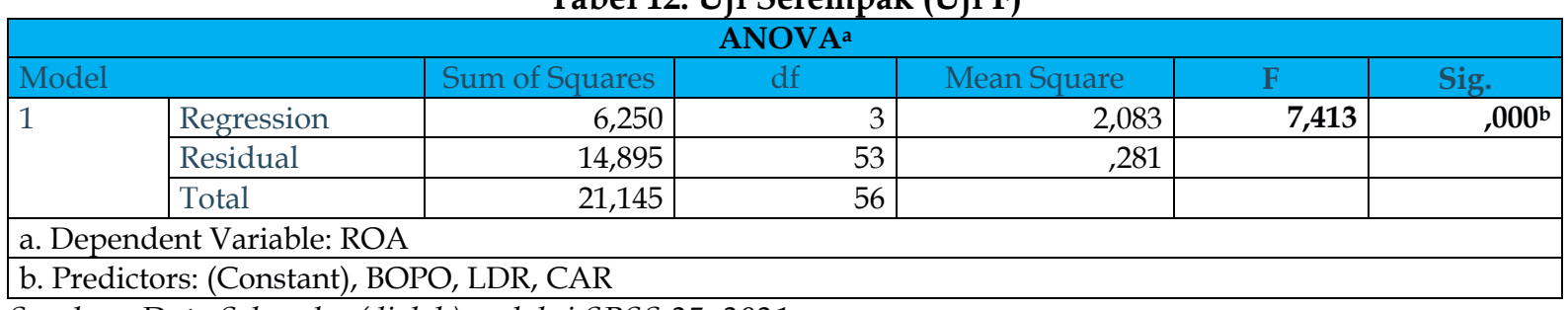

Sumber : Data Sekunder (diolah) melalui SPSS 25, 2021

Berdasarkan tabel output di atas maka diperoleh nilai Fhitung $=7,413$ dan Ftabel $=2,77$ serta nilai signifikan sebesar 0.000 . karena nilai signifikan $0.000<0.05$ dapat disimpulkan bahwa CAR $\left(\mathrm{X}_{1}\right)$, LDR $\left(\mathrm{X}_{2}\right)$, dan $\mathrm{BOPO}\left(\mathrm{X}_{3}\right)$ berpengaruh secara bersama-sama atau srempak terhadap ROA $(\mathrm{Y})$.

\section{4) Uji Parsial (Uji t)}

Uji t dimaksudkan untuk mengetahui apakah terdapat pengaruh secara parsial (individu) dari variabel-variabel independen (CAR, $\mathrm{LDR}$, dan $\mathrm{BOPO}$ ) terhadap variabel dependen (ROA). Adapun yang menjadi dasar dalam pengambilan keputusan untuk uji parsial (Uji t $)$ adalah:

a) Jika t-hitung $>\mathrm{t}$-tabel dan sig $<0.05$, variabel bebas berpengaruh terhadap variabel terikat.

b) Jika t-hitung $<$ t-tabel dan sig $>$ sig 0.05 maka variabel bebas tidak berpengaruh terhadap variabel terikat.

Tabel 13. Uji Parsial (Uji t)

\begin{tabular}{|c|c|c|c|c|c|c|}
\hline \multicolumn{7}{|c|}{ Coefficientsa } \\
\hline & & \multicolumn{2}{|c|}{ Unstandardized Coefficients } & $\begin{array}{l}\text { Standardized } \\
\text { Coefficients }\end{array}$ & \multirow[b]{2}{*}{$\mathrm{t}$} & \multirow[b]{2}{*}{ Sig. } \\
\hline \multicolumn{2}{|c|}{ Model } & B & Std. Error & Beta & & \\
\hline \multirow[t]{4}{*}{1} & (Constant) & 5,250 & 2,538 & & 2,069 & ,043 \\
\hline & CAR & 1,796 & 647 & ,325 & 2,777 & 008 \\
\hline & LDR &,- 357 & 492 &,- 084 &,- 725 & 472 \\
\hline & BOPO & $-3,503$ & 1,069 & -381 & $-3,277$ & 002 \\
\hline
\end{tabular}

Sumber : Data Sekunder (diolah) melalui SPSS 25, 2021

Dari persamaan regresi linear berganda di atas dapat dilihat nilai konstanta sebesar 5,250 hal tersebut menunjukkan bahwa ROA mempunyai nilai sebesar 5,250 variabel-variabel independen (CAR, LDR dan BOPO) dianggap konstan. Variabel CAR memiliki t-hitung sebesar 2,777 dan nilai signifikansi sebesar 0.008 pada tingkat signifikansi 0.05. Dapat disimpulkan bahwa $0.008<0.05$ maka CAR 
berpengaruh positif dan signifikan terhadap ROA. Variabel LDR memiliki t-hitung sebesar -0.725 dan nilai signifikansi sebesar 0,472 pada tingkat signifikansi 0.05. Dapat disimpulkan bahwa $0.472>0.05$ maka LDR berpengaruh negatif dan tidak signifikan terhadap ROA. Variabel BOPO memiliki t-hitung sebesar $-3,277$ dan nilai signifikansi sebesar 0.002. Dapat disimpulkan bahwa $0.002<0.05$ maka BOPO berpengaruh negatif dan signifikan terhadap ROA.

\section{B. Pembahasan}

\section{Pengaruh Capital Adequacy Ratio (CAR) Terhadap Return on Asset (ROA)}

Berdasarkan hasil uji regresi yang dilakukan melalui 19 perusahaan perbankan yang tercatat di Bursa Efek Indonesia dengan periode pengamatan dari tahun 2017 sampai dengan 2019 diperoleh nilai koefisien sebesar 1,796. Hal ini dapat diartikan bahwa peningkatan 1 satuan CAR dapat menyebabkan ROA meningkat sebesar 1,796 sehingga dapat dinyatakan bahwa CAR berpengaruh positif terhadap ROA. Hal ini sesuai dengan teori dari Herman Darmawi (2011) CAR (Capital Adequacy Ratio) adalah rasio kecukupan modal yang berfungsi menampung risiko kerugian yang kemungkinan dihadapi oleh bank. Lebih dari itu jika dilihat dari kondisi empiris dari objek penelitian akan tampak sebagian besar bank mempunyai Capital Adequacy Ratio (CAR) sebesar dari 8\% bahkan mampu mencapai $45 \%$. Semakin tinggi CAR maka semakin baik kemampuan bank tersebut untuk menanggung risiko dari setiap kredit/aktiva produktif yang berisiko. Semakin tinggi tingkat kecukupan modal yang dimiliki perbankan maka akan semakin tinggi Return on Asset begitu pula sebaliknya. Kemudian dari hasil uji parsial menunjukkan bahwa CAR berpengaruh secara positif dan signifikan terhadap ROA. Hasil ini sesuai dengan penelitian yang dilakukan oleh I Gusti Ayu Dwi Ambarwati dan Nyoman Abundanti (2018) Pengaruh Capital Adequacy Ratio, Non Performing Loan, Loan to Deposit Ratio Terhadap Return on Asset yang menunjukkan bahwa Capital adequacy ratio (CAR) berpengaruh positif dan signifikan terhadap Return on Asset (ROA. Capital Adequacy Ratio (CAR) sangat penting untuk memastikan bahwa bank memiliki cadangan yang cukup untuk menyerap sejumlah kerugian yang wajar sebelum bangkrut dan akibatnya akan kehilangan deposan. Secara umum, bank dengan rasio kecukupan modal yang tinggi dianggap aman dan cenderung memenuhi kewajiban finansialnya. Dalam proses penutupan, dana milik penabung lebih diprioritaskan daripada modal bank, sehingga penabung hanya dapat kehilangan simpanannya jika bank mencatat kerugian melebihi modal yang dimilikinya. Dengan demikian, semakin tinggi rasio kecukupan modal bank, maka semakin tinggi pula tingkat perlindungan aset deposan. Jika nilai Capital Adequacy Ratio (CAR) tinggi, maka bank dapat membiayai kegiatan operasional dan memberikan kontribusi yang cukup besar bagi profitabilitas. Peningkatan Capital Adequacy Ratio (CAR) dapat meningkatkan keamanan nasabah yang secara tidak lansung dapat meningkatkan kepercayaan nasabah pada bank tersebut, yang kemudian dapat berdampak positif pada peningkatan Return On Asset (ROA). Dalam melakukan kegiatanya sehari-hari, bank harus mempunyai dana agar dapat memberikan kredit kepada masyarakat. Modal bank terutama dimaksudkan untuk menutupi potensi kerugian yang tidak terduga (unexpected loss) dan sebagai cadangan pada saat terjadi krisis perbankan. Dana tersebut dapat diperoleh dari pemilik bank (pemegang saham), pemerintah, Bank Indonesia, pihak-pihak luar negeri, maupun masyarakat di dalam negeri.

\section{Pengaruh Loan to Deposit Ratio (LDR) Terhadap Return on Asset (ROA)}

Hipotesis kedua yang diajukan bahwa variabel LDR berpengaruh positif dan signifikan terhadap Return On Asset (ROA). Dari hasil penelitian diperoleh nilai koefisien transformasi regresi untuk variabel LDR sebesar -0,357, hal ini berarti bahwa setiap peningkatan LDR sebesar 1 satuan maka ROA akan menurun sebesar $-0,357 \%$. Sehingga LDR berpengaruh negatif terhadap ROA. Loan to Deposit Ratio (LDR) adalah rasio adalah perbandingan jumlah total penyaluran kredit terhadap total dana yang diterima. Nilai negatif pada variabel LDR menunjukkan adanya kenaikan jumlah hutang dan menunjukkan ketergantungan perusahaan pada pihak luar dalam mendanai kegiatan perusahaan tetapi setiap perusahaan tidak dapat menghindarkan diri dari hutang, setiap perusahaan membutuhkan modal kerja yang terkadang tidak bisa didanai oleh keuntungan yang diperoleh. Dalam teori trade off menyatakan kebijakan untuk membiayai investasi dari hutang dapat dibenarkan dengan pertimbangan bahwa antara risiko yang makin tinggi akibat besarnya hutang dan tingkat pengembalian yang diharapkan lebih besar dari risiko yang ditimbulkan dari hutang, sehingga struktur 
modal yang optimal dapat dicapai. Tingkat profitabilitas bank diukur dengan menggunakan Return on Asset (ROA). Jika LDR naik atau tinggi maka pendapatan bank dipastika akan naik, dalam arti memiliki pengaruh yang positif, tentunya sepanjang pemberian kreditnya dilakuka dengan baik sehingga tidak menimbulkan kredit bermasalah. Karena semakin banyak kredit yang diberikan akan semakin tinggi juga pendapatan bunga bank. LDR akan berpengaruh terhadap kesehatan bank karena pada akhirnya jumlah permodalan bank akan naik dengan demikian Capital Adequacy Ratio (CAR) juga akan mengalami kenaikan, hal ini berarti memberi peluang kepada bank untuk melakukan ekspansi kredit baru. Loan to Deposit Ratio (LDR) seringkali digunakan sebagai indikasi untuk menilai kesehatan keuangan perusahaan dalam menjalankan kegiatan usahanya. Dengan menghitung jumlah rasio LDR, maka dapat diketahui pula kemampuan sebuah bank dalam mendapatkan dan mempertahankan nasabah. Apabila penerima dana sebuah bank terus meningkat, maka sumber-sumber dana baru dan nasabah baru berhasil didapatkan. Bagi investor, LDR sangat penting sebagai indikasi yang digunakan untuk mengetahui apakah bank tersebut dioperasikan dengan baik. Apabila penerimaan dana sebuah bank tidak meningkat, bahkan menunjukkan penurunan, maka bank tersebut hanya memiliki sedikit dana untuk dikreditkan. Penyebab naik turunnya Loan to Deposit Ratio (LDR) bisa berasal dari kondisi internal maupun eksternal perusahaan perbankan. Namun secara umum, beberapa faktor yang berpotensi mengubah LDR yang pertama adalah kondisi ekonomi masyarakat yang memengaruhi permintaan kredit dan jumlah simpanan. Bila dana pihak ketiga ini melambat, maka Loan to Deposit Ratio (LDR) akan mengetat. Kedua, jika tren penyaluran kredit melambat, LDR perbankan pun kian longgar. Hal ini juga dipengaruhi oleh pertumbuhan Dana Pihak Ketiga yang cepat. Ketiga, suku bunga yang naik dan turun merupakan kebijakan moneter yang diatur oleh bank sentral. Hal ini juga memengaruhi LDR, yakni bila suku bunga rendah permintaan kredit mungkin meningkat. Kemudian dari hasil uji parsial menunjukkan bahwa LDR berpengaruh secara negatif dan signifikan terhadap ROA hal ini dikarenakan nilai sig $>0.05$. hasil ini sesuai dengan penelitian yang dilakukan oleh Wildan (2018) dimana hasil penelitiannya yaitu LDR berpengaruh negatif dan tidak signifikan terhadap profitabilitas.

\section{Pengaruh Biaya Operasional Pendapatan Operasional (BOPO) Terhadap Return on Asset (ROA)}

Hipotesis ketiga yang diajukan bahwa Biaya Operasional dan Pendapatan Operasional (BOPO) berpengaruh negatif dan signifikan terhadap Return On Asset (ROA). Dari hasil penelitian diperoleh nilai koefisien transformasi sebesar $-3,503$ hal ini berarti setiap peningkatan BOPO sebesar 1 satuan maka akan mengakibatkan ROA menurun sebesar $-3,503$. Koefisien pada variabel $\mathrm{BOPO}$ bertanda negatif menunjukkan bahwa setiap kenaikan nilai BOPO akan menurunkan nilai ROA, Kondisi ini terjadi dikarenakan setiap peningkatan biaya operasi bank yang tidak dibarengi dengan peningkatan pendapatan operasional bank yang akan berakibat berkurangnya laba sebelum pajak, yang akhirnya akan menurunkan Return On Asstes (ROA). Jika kegiatan operasional dilakukan dengan efisien (dalam hal ini nilai rasio BOPO rendah), maka pendapatan yang dihasilkan tersebut akan naik. Selain itu, besarnya rasio BOPO juga disebabkan karena tingginya biaya dana yang dihimpun dan rendahnya pendapatan bunga dari penanaman dana. Dalam perbankan BOPO berpengaruh besar dalam mengukur tingkat efesiensi dan juga kemampuan bank dalam menjalankan kegiatan operasionalnya. Untuk itu setiap bank harus melakukan perbandingan antara jumlah biaya operasional dan pendapatan operasional. Pendapatan operasional yang didapatkan adalah bunga dari nasabahnya sedangkan biaya operasional perusahaan bergantung dari setiap produk atau jasa yang terjual. Untuk mendapatkan pendapatan operasional yang besar, bank harus pandai mencari nasabah agar bank nisa menekan biaya bunga yang lebih minim. Rasio BOPO yang yang cenderung meningkat menunjukkan bahwa bank tersebut tidak mampu mengelola biaya operasionalnya, sementara itu semakin kecil BOPO, maka semakin efektif bank dalam mengelola biaya operasionalnya. Pendapatan operasional didapat dari nasabah bank yang meminjam uang kepada bank, lalu membayar pokok pinjaman ditambah bunga kepada bank, sedangkan biaya operasional dari pihak ketiga adalah individu atau entitas bisnis yang menyimpan dananya dalam bentuktabungan atau deposito ke bank, maka dana yang disimpan nasabah tersebut akan dicatat sebagai hutang oleh pihak bank dan bank akan membayarkan bunga atas simpanan tersebut. BOPO merupakan perbandingan antara biaya operasional dengan pendapatan operasional. Semakin kecil hasil persentase dari BOPO maka suatu bank dinyatakan menjalankan kegiatan operasinya secara efisien, karena biaya operasional lebih sedikit dibandingkan dengan pendapatan operasional. Nilai persentase yang lebih tinggi mengakibatkan laba yang diperoleh 
menjadi rendah, ileh karena itu nilai BOPO berbanding terbalik dengan nilai ROA. Kemudian dari hasil uji parsial menunjukkan bahwa BOPO berpengaruh negatif dan signifikan terhadap ROA, hal ini dikarenakan nilai sig $<0.05$. Hasil penelitian ini sejalan dengan penelitian yang dilakukan oleh Aminah (2017) hasil penelitiannya yaitu variabel BOPO berpengaruh negatif dan signifikan terhadap ROA.

Berdasarkan hasil penelitian dan pembahasan yang telah diuraikan, maka beberapa kesimpulan dari hasil penelitian ini yaitu sebagai berikut :

1. Dari hasil penelitian yang telah dilakukan untuk menguji Pengaruh Capital Adequacy Ratio (CAR) terhadap Return On Asset (ROA), hasil penelitian menemukan bahwa variabel CAR memiliki pengaruh positif dan signifikan terhadap ROA pada perusahaan perbankan yang tedaftar di Bursa Efek Indonesia.

2. Dari hasil penelitian yang telah dilakukan untuk menguji Pengaruh Loan to Deposit Ratio (LDR) terhadap Return On Asset (ROA), hasil penelitian menemukan bahwa variabel LDR memiliki pengaruh negatif dan tidak signifikan terhadap ROA pada perusahaan perbankan yang tedaftar di Bursa Efek Indonesia.

3. Dari hasil penelitian yang telah dilakukan untuk menguji Pengaruh Biaya Operasional dan Pendapatan Operasional (BOPO) terhadap Return On Asset (ROA), hasil penelitian menemukan bahwa variabel BOPO memiliki pengaruh negatif dan signifikan terhadap ROA pada perusahaan perbankan yang tedaftar di Bursa Efek Indonesia.

\section{Saran}

Adapun saran-saran yang dapat diberikan sehubungan dengan hasil penelitian ini adalah sebagai berikut:

1. Bagi peneliti yang akan melakukan penelitian dengan topik yang sama, sebaiknya memperlihatkan dan memahami faktor-faktor lain serta periode penelitian yang lebih banyak sehingga hasil dari penelitian lebih akurat.

2. Bagi perbankan dan pemegang saham sebaiknya mengoptimalkan kinerja perusahaan dengan memperhatikan nilai CAR, LDR, dan BOPO sebagai acuan untuk memprediksi peningkatan terhadap ROA.

3. Bagi investor dapat mempertimbangkan variabel CAR, LDR, BOPO yang secara simultan berpengaruh terhadap ROA sebagai dasar dalam menilai dan memilih saham perusahaan yang lebih menguntungkan.

\section{DAFTAR PUSTAKA}

Abdulrohman, dkk. 2020. Pengaruh Capital Adequacy Ratio (CAR), Loan to Deposit Ratio (LDR), Non Performing Loan (NPL) terhadap Return On Asset (ROA) pada sektor Perbankan yang terdaftar di Bursa Efek Indonesia. Jurnal Revenue. Volume 1 Nomor 1, Juni 2020.

Akbar Taufiq. 2019. Kajian Kinerja Bank pada Perspektif Umum Kegiatan Usaha (BUKU). Uwais Inspirasi Indonesia.

Andrianto,dkk. 2019. Manajemen Bank. Qiara Media. Pasuruan.

Astarina, Ivaliana dan Angga Hapsila. 2015. Manajemen Perbankan. Deepublish. Yogyakarta.

Darmawi, Herman. 2011. Manajemen Perbankan. Jakarta: Bumi Aksara

Dermawan, Syahril dan Purba, Djahotman. 2011. Analisa Laporan Keuangan. Mitra Wacana Media. Jakarta.

Fadlina. 2019. Pengaruh Kecukupan Modal dan Likuiditas terhadap Profitabilitas Perbankan Konvensional di Bursa Efek Indonesia Tahun 2014-2018. Tesis. UMI

Fajari, Slamet dan Sunarto. 2017. Pengaruh car, ldr, npl, bopo terhadap profitabilitas bank ( studi kasus perusahaan perbankan yang tercatat di bursa efek indonesia periode tahun 2011 sampai 2015 ). Prosiding seminar nasional multi disiplin ilmu \&call for papers unisbank ke-3(sendi_u 3) 2017 isbn: 9-789-7936-499-93

Fajria Anindya Utami. 2020. Beban Operasional terhadap Pendapatan Operasional(online).https://www.wartaekonomi.co.id/read300269/apa-itu-bopo/0 diakses pada tanggal 10 November 2020

Farhat, Pinasti Wildan dan Indah Mustika. 2018. Pengaruh CAR, BOPO, NPL, NIM, dan LDR terhadap Profitabilitas Bank Umum. Jurnal Nominal Vol. VII No. 1 Tahun 2018.

Haryani, Iswi. 2010. Restrurisasi dan Penghapusan Kredit macet. PT. Elex Media komputindo Kompas Gramedia. Jakarta

Hasrida.2016. Pengaruh NPL, CAR, LDR, dan BOPO terhadap Return On Asset (ROA) pada Bank BUMN yang terdaptar di Bursa Efek Indonesia. Tesis. UMI Makassar. 
Hery. 2015. Analisis Kinerja Manajemen. Gramedia Widiasarana Indonesia: Jakarta.

https://www.edusaham.com/2019/04/daftar-perusahaan-perbankan-yang-terdaftar-di-bei.html diakses pada tanggal 13 November 2020

https:/ / elib.unikom.ac.id/files/disk1/709/jbptunikompp-gdl-ritarahmaw-35402-9-unikom_r-i.pdf (pengertian NPL Herman Darmawi)

https://www.ojk.go.id/id/kanal/perbankan/data-dan-statistik/statistik-perbankanindonesia/Documents/Pages/Statistik-Perbankan-Indonesia---Desember2019/SPI\%20Desember\%202019.pdf

Ismail. 2015. Akuntansi Bank Teori dan Aplikasi dalam Rupiah. Prenada Media. Jakarta.

Kasmir. 2012. Bank dan Lembaga Keuangan Lainnya. Raja Grafindo Persada:Jakarta

Muctar, Bustari, dkk. 2016. Bank dan Lembaga Keuangan Lain. Kencana. Jakarta.

Muhammad Rauf Sirajuddin. 2017. Pengaruh Tingkat Suku Bunga, Non Performing Loan (NPL), Capital Adequacy Ratio (CAR), Loan to Deposit Ratio (LDR) Terhadap Tingkat Profitabilitas Perusahaan Perbankan yang Tercatat di Bursa Efek Indonesia. Tesis. UMI

Rodoni Ahmad, dan Herni Ali. 2014. Manajemen Keuangan Modern. Mitra Wacana Media. Jakarta.

Septiana, Aldila. 2019. Analisis Laporan Keuangan Konsep Dasar dan Deskripsi Laporan Keuangan. Duta Media Publishing. Jawa Timur

Stevani dan Toni Sudirgo. 2019. Analisis CAR, BOPO, NPL, dan LDR Terhadap ROA pada Perusahaan Perbankan. Jurnal Multiparadigma Akuntansi, Volume 1 Nomor 3/2019.

Suciati, Aprilia, dkk. 2019. Pengaruh CAR, BOPO, NPL, dan LDR terhadap ROA pada Bank BUMN yang terdaftar di Bursa Efek Indonesia. Center Of EconomicStudent Journal Volume 2 Nomor 3 Juli 2019.

Sugiyono. 2012. Metode Penelitian Bisnis. Bandung. Alfabeta

Sujarweni,V. Wiratna. (2017).Analisis Laporan Keuangan : Teori, Aplikasi, \& Hasil Penelitian. Yogyakarta: Pustaka Baru Press.

Suryani, Hendriyadi. 2016. Metode Riset Kuantitatif Teori dan Aplikasi pada Penelitian Bidang Manajemen dan Ekonomi Islam. Prenada Media. Jakarta

Sutra Dewi, Aminar. 2017. Pengaruh CAR, BOPO, NPL, NIM dan LDR terhadap ROA pada perusahaan di sektor perbankan yang terdaftar di BEI. Jurnal Pundi Vol. 01 No. 03 November 2017.

Usman Harun. 2016. Pengaruh Ratio-Ratio Keuangan CAR, LDR, NIM, BOPO, NPL, dan NPL terhadap ROA. Vol 4 No. 1. 68.

Widyatuti, Maria. 2017. Buku Ajar Analisa Kritis Laporan Keuangan. CV. Jakad Media Nusantara. Surabaya.

Yanti, Novi.2013. Analisis Kinerja Perusahaan Perbankan yang Terdaftar di Bursa Efek Indonesia (BEI), Vol 1, No. 2. 168

Yunia Putri Lukitasari dan Andi Kartika. 2015. Analisis Pengaruh Dana Pihak Ketiga, BOPO, CAR, LDR, dan NPL terhadap Kinerja Keuangan Pada Sektor Perbankan yang Terdaftar Di Bursa Efek Indonesia. Infokom. Nomor 1/Th.XI/Maret/2015

Zul, Moh Pratama Lamuda. 2016. Pengaruh Capital Adequacy Ratio(CAR), Loan to Deposit Ratio (LDR), dan BOPO terhadap Return On Asset (ROA) di Perusahaan Perbankan Go Public yang Terdaftar di Bursa Efek Indonesia. Tesis. UMI Makassar. 